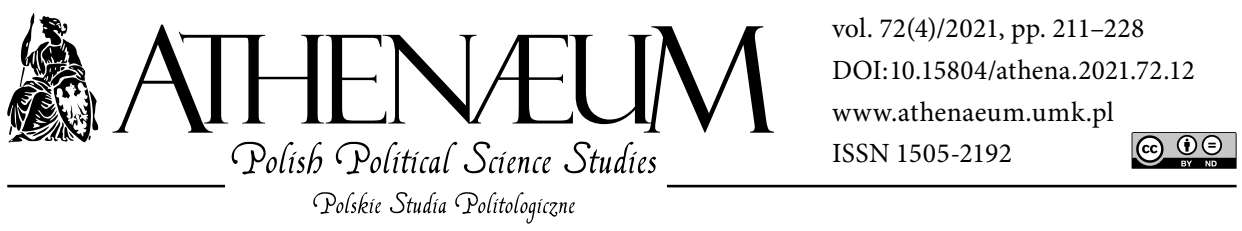

\title{
SHAPING OF SUSTAINABLE POLITICAL SYSTEM IN A SUPRANATIONAL SPACE OF THE EUROPEAN UNION: INSTITUTIONAL PERSPECTIVE
}

\author{
KSZTAŁTOWANIE ZRÓWNOWAŻONEGO SYSTEMU \\ POLITYCZNEGO W PONADNARODOWEJ PRZESTRZENI UNII \\ EUROPEJSKIEJ - PERSPEKTYWA INSTYTUCJONALNA
}

Anna Wierzchowska*

\begin{abstract}
The current study assumes that the notion of sustainable development, typical for the discourse on environmental protection, can be also applied to political research and indicates that institutions play a very important role in the process of creating and maintaining the balance of the political system, the aim of which is to build sustainable relations between different participants in its space. The European Union, which seems to feature characteristics of a hybrid organization and displays strong tendency to increase complexity, is examined. The EU institutions have a very important and often difficult role to play in sustaining intergovernmental and supranational influence and therefore often find themselves in contradictory situations. The intersecting efforts to deepen integration and at the same time the need to protect sovereignty do not allow for straightforward achievement of sus-
\end{abstract}

W niniejszym artykule przyjęto, iż pojęcie zrównoważonego rozwoju poza dyskursem związanym $z$ ochroną środowiska może znaleźć także zastosowanie $\mathrm{w}$ badaniach politologicznych. Pojęcie to wskazuje, że instytucje odgrywają bardzo istotną rolę $\mathrm{w}$ procesie kreowania i utrzymywania równowagi systemu politycznego, którego celem jest budowanie zrównoważonych relacji pomiędzy różnymi uczestnikami jego przestrzeni. Badaną płaszczyzną systemową jest Unia Europejska, nosząca cechy organizacji hybrydowej i przejawiająca tendencje do zwiększania złożoności swojej natury. Instytucje UE mają do spełnienia bardzo ważną, a nierzadko trudną rolę równoważenia wpływów międzyrządowych i ponadnarodowych oddziaływań, co często stawia je w sytuacji sprzeczności. Przecinające się wysiłki na rzecz pogłębiania integracji, a jednocześnie potrzeba ochrony suwerenności

* University of Economics and Human Sciences in Warsaw, Department of Political Sciences. 
tainable development of the integration system. Therefore, a distinctive feature of this system is the maintaining of sustainability rather than the actual achievement of sustainable development.

Keywords: sustainable development; institutional system; European Union; balance; political system nie pozwalają na proste osiąganie zrównoważonego rozwoju systemu integracyjnego. Dlatego też cechą charakteryzującą ten system jest raczej proces równoważenia niż jego realne osiągnięcie.

Słowa kluczowe: zrównoważony rozwój; system instytucjonalny; Unia Europejska; równowaga; system polityczny

\section{INTRODUCTION: THE CONCEPT OF SUSTAINABLE DEVELOPMENT IN POLITICAL SCIENCE}

The current study is an attempt to move the concept of sustainable development beyond the framework of environmental policy and to include it into discussions on political systems.

The main research assumption is the statement that implementation of sustainable development concerns not only individual policies, but the whole political system with its legal and institutional framework. One of the steps to prove it is to draw from the axiological and normative layer of the concept of sustainable development, and to identify the impact it can have on the creation of institutional solutions necessary for building sustainable space of the whole political system. It is based on research of Holden, Linnerud, and Banister who point to sustainable development as a normative system of values compatible with human rights, democracy, and freedom (2017, p. 215). This way we obtain multi-dimensional, and applicable to many systems normative model of sustainable development, based primarily on axiological assumptions, rather than specific guidelines for individual policies that carry out their tasks in relation to maintaining natural resources.

According to traditionally applied interpretations, sustainable development means growth which can be named as current, constant, steady, responsible, and avoiding excess. As James Meadowcroft suggests, the concept of sustainable development was a kind of mantra for the end-of- $20^{\text {th }}$ century debates, and now includes staggering array of terms that involve such categories of social life as: "consumption", “economy", "growth", "income", "standard of living" " "production", "society”, "system", “welfare”, or "productivity”. As a result, we are discussing sustainable culture, sustainable economy, environment, sustainable political and social structures (Meadowcroft, 1997, p. 169). 
It was stressed in the Brundtland Commission's Report of the World Commission on Environment and Development of 1987 that sustainable development should be included in the designed adaptations of social practices and institutions in order to avoid unsustainable social trajectories as the latter involve situations of stagnation and decay (Meadowcroft, 1997, p. 171).

Making development sustainable minimizes the costs of social adjustment, both through crisis avoidance mechanisms and techniques to shape the desired future. In fact, both of those are inseparably connected. The subsequent meetings on sustainable development at the 1992 Rio Earth Summit (UNCED) and at the 2002 World Summit showed that sustainable development is a multi-faceted challenge that can be taken up by many actors (Ward, 2012, p. 41).

Although the discourse on sustainable development in terms of governance is not the main research direction on this issue, there are studies on governance (management) seen as a process of assigning values, procedures, and institutions to the requirements of sustainable development (Lafferty \& Meadowcroft, 1996). Halina Ward refers to the compatibility of sustainable development and the idea of democracy, seen as a socio-political and cultural project with special axiological characteristics. It stresses, above all, the compatibility between the objectives of sustainable development and the principles of implementing democratic governance based on the principle of justice and a participatory decision-making mechanisms, the idea of intergenerational equality and respect for civil rights and freedoms, including the right to information (Ward, 2012, p. 42).

When transferring the considerations to the level of integration processes, one should take into account different political reality in which they take place compared to the national or international perspective.

In case such as the European Union, development takes place in exceptional conditions resulting from characteristics typical for a supranational structure. It means that achieving real common values is more difficult, and the effects of joint actions are dependent on the changing economic and political situation both in the region and world-wide, as well as in individual participants. In effect, to obtain sustainable balanced and favourable development, institutions with their decisive potential and competences need to play supporting and conducive role for the fulfilment of the agreed tasks distributed among various levels of cooperation. In other words, the role of the European institutions is to enable the achievement of the assumed goals in development by making effective decisions in situations where significant differences are involved. It can be presented as follow: 


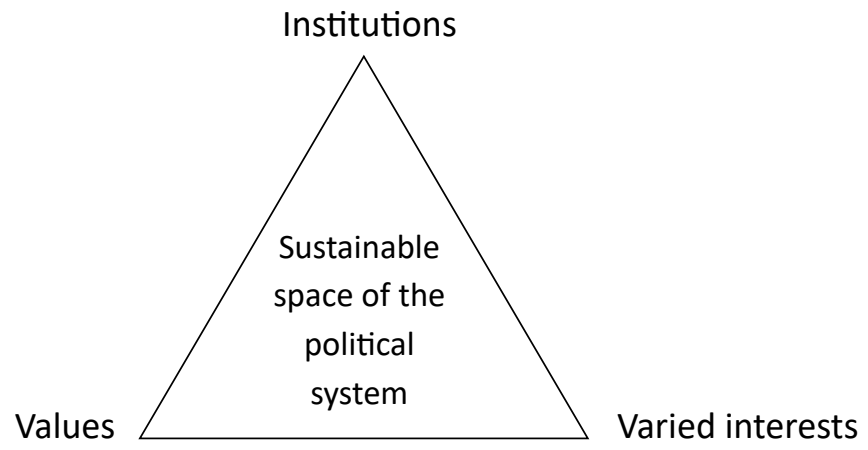

Figure 1. A Model of a Sustainable Political System of the EU

Source: Author's own elaboration based on: Holden et al. (2017, p. 215).

The importance of institutions in the sustainable political system results, to a large extent, from their role in creating the legal plane for its functioning (Jabłoński, 2017, p. 111; March \& Olsen, 1996). The institutional dimension is a structural and organizational basis for the undertaken activities. Legislation requires institutional structures, as does enforcement and control over its proper implementation. The institutions have an enormous influence on maintaining the balance in the development of the system through appropriate and effective distribution of competences and ensuring their proper performance. Together with values and interests they participate in shaping European policies and law, and thus they are co-creators of the rules on which the system functions. At the same time, they are not isolated and separated from other actors, i.e., participants in this process.

Based on the observations, the following hypothesis was formulated: European institutions contribute to shaping the conditions for the implementation of sustainable development of the entire EU system. By delegating competences to individual organs, a structural context is created that may strengthen or weaken the systemic balance and its development.

The main goal of the study is to present institutions in multilevel context and point at manifestations of their influence on the process of shaping a European sustainable system. 


\section{RESEARCH METHODOLOGY}

Sustainable development is not seen as a scientific discipline (Rapport, 2007; Perrings, 2006; Clark, 2007). It is more often characterized as a field of research emerging as a result of interdisciplinary cooperation, but not having strictly defined characteristics of a scientific discipline (separate methodology, coherent research area). As noted by Ostrom, Janssen and Anderies (2007), the interests of biology, ecology, economics, environmental science, geography, history, law, political science, psychology, and sociology should be considered and confronted with the practical aspect of sustainable development in order to achieve a full analytical picture of the phenomenon.

Referring sustainable development to systemic categories of politics and institutions in a supranational context requires the adoption of appropriate theoretical assumptions specific to these phenomena. The reason lies in fact that power delegation to the supranational authorities of the EU was indeed an unprecedented economic and political innovation which attracted magnificent scholastic attention.

For explaining the phenomenon of EU system, theory of complex adaptive systems along with the accent of the resilience concept and multilevel governance perspective can be used. Institutions are perceived in context of elements of complex multilevel system.

Generally, the paradigm of complexity is based on a systemic approach in creating vague, multivalent, multi-level and multidisciplinary representations of reality. Systems are explained in the process of searching for complexity patterns and mechanisms describing their potential evolution. The descriptions are unspecified, complementary, and dependent on the observer. Systems naturally move between balance points through environmental adaptation and selforganization; however, control and order are emergent rather than hierarchical (Dooley, 1997, p. 46; Dooley, 2004; Lewin, 1992; Waldrop, 1992). The theory of complex adaptive systems (CAS) itself resulted from the discovery of chaotic system behaviors, which does not mean compatibility between chaos theory and complex adaptive systems. The theory of complex adaptive systems allows for a holistic perspective of the organization and functioning of the system. It is both a way of self-organization and a learning process, and examples of this are found in ecological, social, political, cultural, climatic, and technological settings (Dooley, 1997, p. 77). Looking for the possibility of applying this approach, 
Dooley points out that it is useful in the research on autopoietic systems, dispersed systems, system dynamics and chaotic dynamics of change.

In a complex system reality, it is important to develop mechanisms to restore the system to equilibrium whenever significant alterations occur. What is crucial, however, is to emphasize that it is a matter of permanent incorporation of such instructions and skills, which will always work (or will work in most cases) and will be a natural part of the functioning of a given system. Therefore, these are not ad hoc instruments created from the very beginning, but already existing procedures and tools, allowing for efficient and effective adaptation of the current action to the requirements of the crisis or some unusual situation. They provide the system with resilience and adaptability. This property allows research to be undertaken from the perspective of resilience. The category of resilience puts emphasis on creating conditions that favour better adaptation and innovation and strives to strengthen self-organisation and the emergence of adaptive behaviour, not designing closely-managed programs (Wierzchowska, 2017, p. 17). For research on supranational integration space, resilience is a way of explaining the adaptive properties of the EU political system, which is characterised, above all, by a specific combination of purposeful and predictable operation with unpredictable changes, correcting the original assumptions. It is the interpretation of the mechanism of maintaining (or losing) the systemic balance.

The conceptual relationship between the assumptions of the complex adaptive system theory and the resilience approach is natural and involves a need to understand and interpret complex reality, present in both perspectives. Complex system development dynamics are subject to heterogenous conditions, which include uncontrollable external impacts, as well as planned projects aimed at achieving long-term, far-reaching, and sustainable developmental effects. Thus, the concept of sustainable development becomes a component of a broader approach, the framework of which is determined by the complexity of the phenomenon.

A theory that is already deeply rooted in the research space of integration processes, and which in its overtone refers to thesis presented by CAS, is multilevel governance (MLG). As Tanja Börzel writes, referring to Gary Marks, MLG focused on "continuous negotiation among nested governments at several territorial tiers" (2020, p. 778).

Generally multilevel governance (MLG) implicitly or explicitly relates to problem-solving. In a nutshell, MLG is a concept which lets to understand the interaction between a multiplicity of actors across different levels of govern- 
ment, akin to the phenomenon of overlapping jurisdictions in political space (Maggetti \& Trein, 2019, p. 357, after: Hooghe, Marks \& Blank, 2003, p. 236). Multilevel-governance Europe is "based on coordinated action by the European Union, the Member States and regional and local authorities according to the principles of subsidiarity, proportionality and partnership, taking the form of operational and institutional cooperation in the drawing up and implementation of the European Union's policies". The most important systemic diversity in the $\mathrm{EU}$ is the difference between the supranational and intergovernmental levels of cooperation. In fact, we are not talking about a clear contradiction, but we can certainly talk about moving on a continuum at the two poles of which there are intergovernmental and supranational policies.

The multi-level approach assumes and builds into the image of the institutional structure its internal disharmony, contradictory and often also collision. The necessity to operate within several decision-making and participatory levels, while taking into account common values and often different interests, may lead to reaching the point where the system is overloaded and it is difficult to find its functionality in a given scope. This can be illustrated by the crisis situations that the European Union has experienced for over a decade.

On the path of theoretical considerations of the conducted research, there is also a reference to the institutional dimension. Institutional design plays essential role in studies over sustainable development. For all planning, institutions are critical; this is equally true of planning for sustainable development. But in such a complex environment like the EU, the perception of institutions requires a specific approach that will certainly deviate from the vision consistent with the traditional theory of institutionalism, within which three schools are distinguished: the historical approach, the 'rational choice' approach, and the sociological approach. Leaving a detailed description of individual trends, it can be concluded that to indicate the role of institutions as actors striving to strengthen a sustainable system, the institutionalism of rational choice seems to be the most appropriate, even though not sufficient. Clearly this approach is highly compatible with normative institutional analysis based on a 'logic of efficiency' that leads directly to 'objective' institutional design. Nevertheless, its theoretical models and analytical tools can also be deployed in a dialogical-recursive process of institutional analysis and design. This school of thought also attributes the origin of institutions to deliberate design and voluntary agreement (Alexander, 2005, p. 212).

Summarizing the theoretical research, it can be concluded that regarding the methodological assumptions for explaining sustainable development in the 
conditions of European integration, it is necessary to refer to a group of concepts that do not always belong to the traditional family of European theories.

\section{RESEARCH RESULTS: THE ROLE OF EUROPEAN INSTITUTIONS IN THE PROCESS OF BALANCING THE EU SYSTEM}

The key question in analysing political system of the EU is its supranational dimension. The functioning of the EU as a supranational organization is based on the implementation of a wide variety of systemic mechanisms which allow for multi-level cooperation (Stein \& Turkewitsch, 2010, pp. 3-5; Borg, 2012; Jessop, 2010; Marks, Hooghe, \& Blank, 1996, pp. 342-378). The participants of this cooperation are part of a complex system. The system's basic aspiration is development based on balance and mutual respect for each other's differences within the rules and axiological framework of democracy. Balancing appears to be the essence of an integration system that is in fact based on contradictions. As noted by Piattoni (2015, p. 240) in more detail, these contradictions include: function vs. territory; large states vs. small states; division of power vs. the rule of balance; politics vs. law. This requires that the participants in the system (states, citizens, institutions) communicated internally and displayed their readiness to act responsibly towards each other and globally. The contradictions of the system tend to fragment the institutional architecture of the EU, which means that they must be controlled but also used wisely to keep the whole structure intact.

The institutional dimension of this system takes on special features, adjusting to the needs and real requirements of the developed cooperation, which is subject to constant influence from both crises and modernization phenomena (Wierzchowska, 2016; Czachór, 2013). When opposed, the influences make the political system of the European Union exhibit features of a structure based on strong uncertainty and linearity in development. Dependence on complex internal factors and external conditions make the integration process and its structure a phenomenon characterized by a unique relational system and a complicated system of participation. As Tomasz Kownacki stresses: "The European Union should be seen as a unique, multi-level political system characterized by the coexistence and interaction of actors at regional, national and European levels (as well as various functional players, such as interest groups, etc.)" (2021, p. 26).

In pursuing its objectives as an international organization, the European Union has developed a specific way of functioning based on institutions sup- 
porting the development of the whole system, which is often affected by crisis factors. The latter manifest themselves in various forms and are caused by various factors. The original determinant of the crises of the EU system is its internal diversity built upon the membership of more than twenty different state entities, together with their expectations, aspirations, and potentials.

The European institutions are important regulator of the social life of EU citizens, thus providing a stable structure for human activity (North, 1990). But the question is whether the EU institutions can contribute to eliminating or strengthening the process of building sustainable objectives of the system in any way. The EU institutions form a unique system of connections between competences, people and functions and should not be seen as disconnected from all subordinate structures serving the objectives of the whole community (Hardacre, 2011). They can be described as interconnected, strong relationships between the participants of the process, implementing the objectives that are important for the countries that are co-creating it. Without efficient communication, as well as a cooperation-oriented approach in achieving common benefits, including economic ones, it is impossible to achieve positive effects. Management structures and institutional quality go hand in hand with good and sustainable economic performance (Acemoglu \& Robinson, 2012; Acemoglu, Johnson, \& Robinson, 2005). However, there are significant differences in institutional quality between EU member states. The observed regression in some countries is a wake-up call for improving institutions (Lagarde, 2018) in order to promote sustainable economic performance for the countries themselves and the EU as a whole (Demertzis, Sapir, \& Wolff, 2019, p. 11).

The entire institutional set-up of the EU is constructed in accordance with the principle of counteracting the concentration of power by one of the institutions, but this does not fully correspond to the principle of state separation of powers (Kreppel, 2011). The principle of institutional balance is not explicitly proclaimed in the Treaties, but is derived from their content and context, as stated on several occasions by the Court of Justice of the European Communities (CJEC) (Galster, 2014, p. 110). It is not a matter of exact equity of institutional competences and powers, but rather of maintaining balance between the supranational and intergovernmental components (Wierzchowska, 2019, p. 38). This type of balancing is, in a way, superimposed on the principle of balance seen as an arrangement of relations between the powers and position of individual institutions. What we understand as a specific type of cooperation based on mutual respect and restraint can also be the basis for conclusions on conflicting inter-institutional 
relations. Institutional issues have a significant impact on the balance of power between large and small EU member states, and thus indirectly on the distribution of the EU budget (Frohlich, 2000, p. 13).

The Lisbon Treaty in Art. 9, sub-section 2, highlights and delimits the boundaries activities of European institutions, i.e., a kind of legitimacy of its functioning, indicating that each institution operates within the limits of powers conferred on it by the Treaties, in accordance with the procedures, conditions and objectives set out in them. Institutions should cooperate smoothly with each other. This provision of the ratified treaty places clear requirements on the role, activity and harmony of the European institutions (Broniszewski, 2018, p. 27).

Institutional development of the EU is a history of changes, which are a kind of march towards increasing the powers of individual organs, with simultaneous violating the previously established systemic balance. And while some of these modifications allowed the system to achieve the necessary balance by granting competences to those institutions whose voice was definitely ignored or hardly heard, there were also situations when new powers were negatively accumulated. In a particular way, the increasing parliamentarization of the integration process contributed to a change in the internal system equilibrium. Instead of separation of power, the system was pushed towards a parliamentary system of fusion of power (Poptcheva, 2019, p. 43). The growing importance of the European Parliament is usually assessed positively, primarily as a manifestation of the democratization of the political life of the EU. Beginning with the Single European Act (1986), through the Treaty of Maastricht (1992) and the Treaty of Lisbon (2007), the European Parliament gained more powers and strengthened its position in the institutional system. Each time, the effect of a new equilibrium in the system appeared, which strengthened the importance of supranational influences.

Interinstitutional relations between the EP and the European Council are increasingly characterized both by the need for partnership and cooperation in some instances and at the same time by some strong and significant inbuilt rivalries and tensions (Gomez, Wessels, \& Wolters, 2019, p. 55). But the same can be said about relations with the European Commission or the Council. The problem of shaping a balanced system with the participation of the indicated institutions is clearly visible on the example of the use of the Spitzenkandidaten mechanism in 2019. Its use in 2014 strengthened the positions of the EP and European political parties, which, through the nominations of the main candidates for 
the president of the European Commission, thus indirectly became institutions influencing the formation of a political body of fundamental importance in the EU system.

The re-use of this instrument in 2019 showed the unique situation of the internal institutional game for influence and at the same time became the source of a crisis in the system. Encouraged by the success of 2014, the European Parliament expressed its wish to re-refer to the procedure of nominating the lead candidates. However, the European Council considered that it could not guarantee that its candidate would be one of those previously elected by the parties. Referring to the provisions of the Treaty, the leaders stated that the process of electing the President of the EC is not automatic and the presentation of the candidate falls under the autonomous competence of the European Council. The leaders ignored the EP's warning, which signaled that it would not accept a candidate for the head of the EC after the election, if the candidate was not nominated by one of the European parties.

The behavior of the European Council shows clearly that the Spitzenkandidaten procedure was not considered as a viable solution and indicates a lack of interinstitutional solidarity. The democratizing influence, which was the main aim from the EP's point of view, was not seen in the same way by the European Council, which was not interested in empowering the EP at the expense of its own competences (Wierzchowska, 2021).

The mechanism proposed in 2014 has not gained institutional sustainability in the EU system. However, the Spitzenkandidaten story can be considered to be part of cycle of institutional conflict in the EU. Its implementation (if continued) will become a gateway to circumvent the Treaty restriction preventing the EP from formally proposing a candidate for the post of Head of the Commission. Shifting the burden of responsibility to the factions offers an opportunity to ensure the democratic legitimacy of the European citizen's vote to its candidate, thus creating normative pressure on European governments to nominate the elected candidate. Ultimately, if the normative power was not sufficient, the EP could threaten to block any alternative candidate proposed by the governments (Schimmelfennig, 2014).

In the history of European integration institutions were always active creators of changes, stimulating the development of the entire system, balancing the influences of the most competitively minded participants, as well as deepening potentially existing conflicts. Ipso facto they are shaping the balance of the whole system. Through successful projects and failures resulting from unsuccessful 
attempts to implement changes, they react to new challenges and become one of the first entities to experience modifications introduced.

Looking at the problem in the light of the recent changes that the EU political system has experienced as a result of the ratification of the Treaty of Lisbon, it can be concluded that this system, from the institutional perspective, has changed from the triangle model to the quadrilateral model.

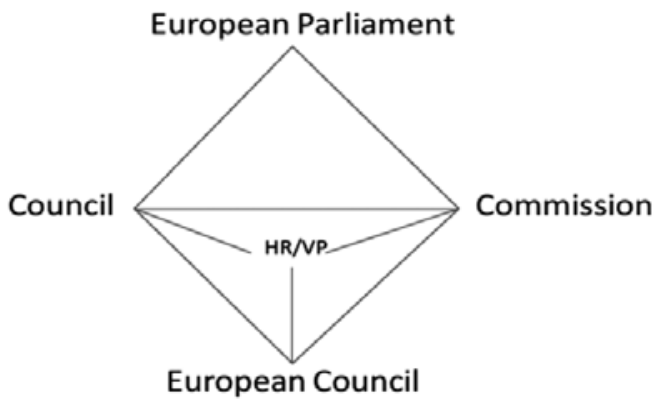

Figure 2. Post-Lisbon Institutional Quadrilateral

Source: Monar (2011).

This was done, first of all, due to the formal strengthening of the position of the European Council, which was entered into the main EU institutions, indicated by Article 13 of the TEU. Thus, the entire decision-making system was strengthened by the second, after the Council, intergovernmental institution, with already existing supranational bodies such as the Commission and the European Parliament. And even if we treat it only formally (the European Council has been in existence since the 1970s), the precedent with the Spitzenkandidaten mechanism in 2019 may prove that this step in practice strengthened the position of the European Council.

Generally, these were the EP and the European Council that became the main beneficiaries of the changes in the European post-Lisbon system of institutional power. By granting the European Parliament greater powers in the field of fiscal policy, the Lisbon Treaty has established a very important element of the policy-making chain, allowing a kind of pressure to be exerted on the legislative, budgetary and control powers of the European Commission. In turn, legislation has diminished the power of the Commission, as has the relative weight of the Council with the strengthened position of the European Council. The latter gives 
the Union a strategic direction, guides, as well as limits and controls the activities of the Commission. It can be considered that it has assumed the position of a superior in relation to the Commission.

The Treaty of Lisbon, changing the architecture of the EU and its institutional balance, entered into force more than ten years ago, but did not end the evolution of the political system. Seeking their place in the new system, the EU institutions have made and are still making significant shifts and modifications in the established cooperation mechanism. Is it possible to talk about building a balanced system at the same time?

\section{CONCLUSIONS}

EU creates a specific laboratory of various agents and structures cooperating with each other at various levels, in which governmental structures still have a significant place. In this way (again and again), a unique network of institutional connections is created, exposed to constant shocks, inconsistent stimuli directed from various parts of the system environment (Leonard, 2000, pp. 45-46). Institutional conflict is built into the system. Tensions occur on both the supranational-intergovernmental line and at the division of power: the Council and the Commission are regularly in dispute over the division of executive power, the European Parliament is confronted with the Commission while national parliaments feel alienated from the Union and claim for the role of the European Parliament in the decision-making process (Leonard, 2000, p. 42). One can get the impression that institutions entering into particular relationships with each other "forget" about the network, open and interdependent arrangement and often try to "win" something for themselves. But this is only one side of the coin. The second one, more optimistic, is based on the principle of solidarity and loyal cooperation. Both tendencies build complexity of the system. The institutional aspect of this complexity plays a very important role. Of particular importance is the fact that the same actors play different roles in the political process played in the integration space, and the complexity of interdependencies that occur in the European system goes beyond the known and explained rules at the national level (Wierzchowska, 2016, p. 395).

Efforts to build and maintain a sustainable EU system are connected with the constant overcoming of the various aspirations and ambitions of the participants in the integration process. This is done through activities undertaken by Euro- 
pean institutions which, striving to pursue represented interests, contribute to strengthening or upsetting the balance of the system.

Certainly, the system operates under highly stressful and destabilizing conditions, which exposes it to frequent conflicts and therefore requires numerous adaptive and corrective measures. Each time the aim is to regenerate the system and return to balance. In this particular cycle of events and their aftermath, the institutions that are responsible for developing the new rules and give the structural framework to the decision-making processes have a unique role to play. The institutions absorb all the imbalances and disruptions in the integration process and at the same time have an important duty to rebalance it. The ability to adapt, absorb hardships and recover stable functioning - these are the fundamental capabilities of the integration system.

But even when assuming an optimistic attitude, one must not forget that: "The EU today is prone to conflict because 'tossed salad' members in response to changing global realities no longer share a common view of acceptable supranational government. Some EU members are contemplating exiting because they perceive themselves to be victims of what for them is a negative sum game" (Rosefielde, 2019, p. 143). It means that obtaining balanced development is dependent on many factors and the European Union's institutional system has not always supported this process. Despite the assumption of sustaining influence and competence, it has often become a source of dysfunction for the organization. This is evidenced by the reforms stemming from the Treaty of Lisbon, which, although aimed at deepening integration and strengthening supranational elements, in political practice have often pointed to the opposite direction, that is, the continuous strengthening of intergovernmental features (Grosse, 2016, pp. 282-293, as cited in: Tosiek, 2017, p. 371). Michael Burgess cites the notion of endemic institutional incapacity, which, in his opinion, is a form of crisis that sometimes hinders European integration (and thus distancing it from the sustainable state) but at the same time offers new political opportunities and generates new systemic solutions, including in the federal direction (Burgess, 2015, p. 183). This means that the phenomenon of sustainable development in relation to the European Union's political system is not transparent regarding its implementation. The Union strives for balance and constantly creates new institutional solutions to contribute to this goal. However, the need to "extinguish fires" caused by crises has often made it necessary to turn from the chosen course of sustainable development, which is understood as modernizing the system, and to focus on searching for solutions allowing for the system's survival. At that time, 
the EU institutions were making efforts to create a favourable legal and organizational environment to counteract the influence of destabilizing factors. Back in 2000 , before there were introduced the changes that are now considered to be the most revolutionary for the integration system (2004 enlargement, crisis events after 2008), Stefan Frohlich noted: "Ultimately, it is clear that well-functioning institutions and efficient decision-making procedures will benefit the Union as an organization as well as its current and future members. It will become easier to solve the problems they encounter and to deal with internal and external threats to the Community and its individual members" (2000, p. 14). Can we make a more explicit statement that would indicate the validity of addressing the issue of institutions in the context of sustainable systemic development?

\section{ReFERENCES:}

Acemoglu, D., Johnson, S., \& Robinson, J. (2005). Institutions as the Fundamental Cause of Long-Term Growth. In: P. Aghion, \& S. Durlauf (Eds.). Handbook of Economic Growth (pp. 385-472). North-Holland, Amsterdam: Elsevier.

Acemoglu, D., \& Robinson, J.A. (2012). Why Nations Fail: The Origins of Power, Prosperity and Poverty. New York: Crown Business.

Alexander, E.R. (2005). Institutional Transformation and Planning: From Institutionalization Theory to Institutional Design. Planning Theory, 4(3), 209-223. DOI: $10.1177 / 1473095205058494$.

Baneliene, R., \& Melnikas, B. (2020). Economic Growth and Investment in R\&D: Contemporary Challenges for the European Union. Contemporary Economics, 14(1), 38-57. DOI: $10.5709 / \mathrm{ce} .1897-9254.331$.

Borg, J. (2012). Is "Multi-Level Governance" a Victim of Conceptual Overstretch? Retrieved August 13, 2020 from: https://www.e-ir.info/2012/08/27/is-multi-levelgovernance-a-victim-of-conceptual-overstretch/.

Börzel, T.A. (2020). Multilevel Governance or Multilevel Government? The British Journal of Politics and International Relations, 22(4), 776-783. DOI: 10.1177/1369148120939872.

Broniszewski, M. (2018). Matryca instytucjonalna Unii Europejskiej w procesie integracji europejskiej. Kwartalnik Naukowy Uczelni Vistula, 3, 25-37.

Clark, W.C. (2007). Sustainability Science: A Room of Its Own. Proceedings of the National Academy of Sciences of the United States of America, 104(6), 1337-1339. DOI: 10.1073/pnas.0611291104.

Czachór, Z. (2013). Kryzys i zaburzona dynamika Unii Europejskiej. Warszawa: Dom Wydawniczy ELIPSA.

Dehousse, R. (2015, August 26-29). The New Supranationalism. Paper Prepared for Presentation at the ECPR General Conference Panel P298. Reflections on the Euro-crisis and the Future of Representative Democracy Montreal. Retrieved 
from: https://paperzz.com/doc/7033891/the-new-supranationalism---europeanconsortium-for-political.

Demertzis, M., Sapir, A., \& Wolff, G.B. (2019, April 4). Promoting Sustainable and Inclusive Growth and Convergence in the European Union. Bruegel Policy Contribution, 7 (pp. 1-21). Brussels: Bruegel. Retrieved from: https://www.bruegel.org/2019/04/promotingsustainable-and-inclusive-growth-and-convergence-in-the-european-union/.

Dooley, K. (1997). A Complex Adaptive Systems Model of Organization Change. Nonlinear Dynamics, Psychology, and Life Science, 1(1), 69-97. DOI: 10.1023/A: 1022375910940.

Dooley, K. (2004). Complexity Science Models of Organizational Change. In: S. Poole, \& A. Van De Ven (Eds.). Handbook of Organizational Change and Development (pp. 354-373). Oxford: Oxford University Press.

Fabbrini, S. (2015). Alternative Views of the European Union: Which Institutional Architecture for a Political Union? In: S. Piattoni (Ed.). The European Union: Democratic Principles and Institutional Architectures in Times of Crisis. Oxford: Oxford University Press. DOI: 10.1093/acprof:oso/9780198716273.003.0009.

Frohlich, S. (2000). Reformy instytucjonalne i rozszerzenie - dwa wielkie wyzwania dla Unii Europejskiej. Studia Europejskie, 4, 11-23.

Galster, J. (2014). Zasada równowagi instytucjonalnej w orzecznictwie Trybunału Sprawiedliwości Unii Europejskiej. Gdańskie Studia Prawnicze, 31, 109-120.

Grosse, T.G. (2016). Podsumowanie: w kierunku teorii dezintegracji regionalnej. In: T.G. Grosse (Ed.). Polityki europejskie w dobie kryzysu (pp. 293-302). Warszawa: Wydawnictwo Naukowe Scholar.

Hardacre, A. (Ed.) (2011). How the EU Institutions Work and... How to Work with the EU Institutions. London: John Harper Publishing.

Hoffmann, S. (1982). Reflections on the Nation-State in Western Europe Today. Journal of Common Market Studies, 21(1), 21-38. DOI: 10.1111/j.1468-5965.1982.tb00637.x.

Holden, E., Linnerud, K., \& Banister, D. (2017). The Imperatives of Sustainable Development. Sustainable Development, 25(3), 213-226. DOI: 10.1002/sd.1647.

Jabłoński, A. (2017). Instytucjonalne aspekty teorii polityki. Teoria polityki, 1, 107-126. DOI: $10.4467 / 00000000$ TP.17.006.6585.

Kownacki, T. (2021). Diagnosis the European Union's legitimacy Crisis - Demands for Changes. On-line Journal Modelling the New Europe, 35, 25-43. DOI: 10.24193/ ojmne.2021.31.02.

Kölliker, A. (2001). Bringing Together or Driving Apart the Union? Towards a Theory of Differentiated Integration. West European Politics, 24(4), 125-151. DOI: $10.1080 / 01402380108425468$.

Kreppel, A. (2011). Looking "Up", "Down" and "Sideways": Understanding EU Institutions in Context. West European Politics, 34(1), 167-179. DOI: 10.1080/01402382.2011.523551.

Lafferty, W. (1996). The Politics of Sustainable Development: Global Norms for National Implementation. Environmental Politics, 5(2), 185-208. DOI: 10.1080/09644019608414261. 
Lafferty, W., \& Meadowcroft, J. (1996). Democracy and the Environment: Problems and Prospects. Cheltenham-Brookfield: Edward Elgar.

Lenaerts, K., van Nuffel, P., \& Bray, R. (2005). Constitutional Law of the European Union. London: Sweet \& Maxwell.

Leonard, M. (2000). Sposób na Europę. Pomiędzy federalizmem a Europa narodów. Warszawa: Instytut Spraw Publicznych.

Lewin, R. (1992). Complexity: Life at the Edge of Chaos. New York: MacMillan.

Low, B., Ostrom, E., Simon, C., \& Wilson, J. (2003). Redundancy and Diversity: Do They Influence Optimal Management? In: F. Berkes, J. Colding, \& C. Folke (Eds.). Navigating Social-Ecological Systems: Building Resilience for Complexity and Change (pp. 83-114). Cambridge: Cambridge University Press.

Maggetti, M., \& Trein, P. (2019). Multilevel Governance and Problem-Solving: Towards a Dynamic Theory of Multilevel Policy-Making? Public Administration, 97(2), 355-369. DOI: 10.1111/padm.12573.

March, J.G., \& Olsen, J.P. (1996). Institutional Perspectives on Political Institutions. Governance: An International Journal of Policy, Administration, and Institutions, 9(3), 247-264. DOI: 10.1111/j.1468-0491.1996.tb00242.x.

Marks, G., Hooghe, L., \& Blank, K. (1996). European Integration from the 1980s: State-Centric v. Multi-level Governance. Journal of Common Market Studies, 34(3), 341-378. DOI: 10.1111/j.1468-5965.1996.tb00577.x.

Meadowcroft, J. (1997). Planning for Sustainable Development: Insights from the Literatures of Political Science. European Journal of Political Research, 31(4), 427-454. DOI: $10.1023 / \mathrm{A}: 1006815730614$.

Meadowcroft, J. (2007). Who Is in Charge Here? Governance for Sustainable Development in a Complex World. Journal of Environmental Policy \& Planning, 9(3-4), 299-314. DOI: 10.1080/15239080701631544.

Monar, J. (2011). The European Union's Institutional Balance of Power after the Treaty of Lisbon. In: European Commission (Ed.). The European Union after the Treaty of Lisbon. Visions of Leading Policy-Makers, Academics and Journalists (pp. 60-89). Luxembourg: Directorate-General for Education, Youth, Sport and Culture (European Commission).

North, D.C. (1990). Institutions, Institutional Change and Economic Performance. Cambridge: Cambridge University Press.

Ostrom, E., Janssen, M.A., \& Anderies, J.M. (2007). Going beyond Panaceas. Proceedings of the National Academy of Sciences USA, 104(39), 15176-15178. DOI: 10.1073/ pnas.0701886104.

Perrings, Ch. (2006). Resilience and Sustainable Development. Environment and Development Economics, 11(4), 417-427. DOI: 10.1017/S1355770X06003020.

Piattoni, S. (2015). European Union Institutional Architectures. In: S. Piattoni (Ed.). The European Union: Democratic Principles and Institutional Architectures in Times of Crisis. Oxford: Oxford University Press. DOI: 10.1093/acprof: oso/9780198716273.003.0012. 
Rapport, D.J. (2007). Sustainability Science: An Ecohealth Perspective. Sustainability Science, 2(1), 77-84. DOI: 10.1007/s11625-006-0016-3.

Resolution of the Committee of the Regions on the Charter for Multilevel Governance in Europe (106 th Plenary Session, April 2-3, 2014).

Rosefielde, S. (2019). Salvaging the EU: Two-Speed or Dual-Track Reform? Contemporary Economics, 13(2), 137-146. DOI: 10.5709/ce.1897-9254.304.

Ruszkowski, J. (2013). Struktura wielopoziomowego zarządzania w Unii Europejskiej. In: J. Ruszkowski, \& L. Wojnicz (Eds.). Multi-level Governance w Unii Europejskiej (pp. 19-61). Szczecin-Warszawa: Instytut Politologii i Europeistyki Uniwersytetu Szczecińskiego, Instytut Europeistyki Uniwersytetu Warszawskiego

Stein, M., \& Turkewitsch, L. (2010). Multilevel Governance and Federalism: Closely Linked or Incompatible Concepts? Participation: Bulletin of the International Political Science Association, 34(2), 3-5. Retrieved from: https://www.ipsa.org/sites/ default/files/participation/participation_34-2_web.pdf.

Tosiek, P. (2017). „Demokracja międzyrządowa” - w kierunku rekonstrukcji polskiej koncepcji reformy instytucjonalnej UE. Rocznik Integracji Europejskiej, 11, 369-381. DOI: 10.14746/rie.2017.11.26.

Waldrop, M.M. (1992). Complexity: The Emerging Science at the Edge of Chaos. New York-London-Sidney-Tokyo-Singapore-Toronto: A Touchstone Books-Simon and Schuster.

Ward, H. (2012). Key Concepts: Sustainable Development and Governance. In: H. Ward, ISO 26000 and Global Governance for Sustainable Development (pp. 38-51). London: International Institute for Environment and Development. Retrieved from: https:// pubs.iied.org/sites/default/files/pdfs/migrate/16507IIED.pdf.

Wierzchowska, A. (2016). Wpływ modernizacji i kryzysu na dynamike zmiany w Unii Europejskiej. Warszawa: ELIPSA.

Wierzchowska, A. (2017). The European Union in Search of Systemic Balance: An Analysis Involving the Concept of Resilience. Przeglad Europejski, 4, 10-38.

Wierzchowska, A. (2019). Parlament Europejski: efektywny katalizator zmian ustrojowych czy niedecyzyjny współuczestnik? Ocena pozycji Parlamentu Europejskiego w systemie politycznym Unii Europejskiej z uwzględnieniem kadencji 2014-2019. In: A. Nitszke, \& J.J. Węc (Eds.). Podsumowanie VIII kadencji Parlamentu Europejskiego. Wyzwania integracji europejskiej w latach 2014-2019 (pp. 37-59). Kraków: Księgarnia Akademicka. DOI: 0.12797/9788381380881.02.

Wierzchowska, A. (2020). Complexity of the European Union System and its Adaptation Abilities. International Journal of Innovation, Creativity and Change, 13(5), 776-791. Wierzchowska, A. (2021). Dismantling of the Spitzenkandidaten Mechanism after the 2019 European Elections - Failure of EU Democracy or Political Pragmatism? On-line Journal Modelling the New Europe, 35, 60-91. DOI: 10.24193/ OJMNE.2021.35.04.

Wildavsky, A.B. (1988). Searching for Safety. New Brunswick-Oxford: Transaction Publishers. 